\title{
Pengaruh Pendidikan Kesehatan "Sarapan Sehat" Dengan Media Video Terhadap Pengetahuan dan Sikap Siswa
}

\author{
Tetti Solehati ${ }^{1}$, Cecep Eli Kosasih ${ }^{2}$, Mamat Lukman ${ }^{3}$ \\ 1,2,3Fakultas Keperawatan, Universitas Padjajaran, Bandung, Jawa Barat
}

Corespending author: tetti.solehati@unpad.ac.id

DOI: $\underline{\text { https://doi.org/10.33859/dksm.v10i1.384 }}$

\begin{abstract}
Abstrak
Latar belakang: Sarapan merupakan suatu hal yang penting bagi pertumbuhan dan perkembangan anak, tetapi sering diabaikan, hal ini dapat beresiko pada kesehatan anak dan prestasi belajar anak. Tujuan: Mengetahui pengaruh Pendidikan kesehatan "Sarapan" terhadap pengatahuan dan sikap siswa sekolah dasar.

Metodologi: Penelitian dilakukan di Kabupaten SDN Bojong Asih, SDN Leuwi Bandung Bandung SDN Cangkuang, SDN Pasawahan. Desain penelitian quasi eksperimen dengan rancangan pre test dan post test. Populasinya adalah seluruh siswa kelas 4- 6 berjumlah 323 orang. Sample yang digunakan total sampling. Intervensi diberikan dalam bentuk pendidikan kesehatan menggunakan video tentang sarapan sehat. Semua siswa diberikan quisioner sebelum dah setelah intervensi untuk mengukur tingkat pengetahuan dan sikap.

Hasil: Hasil penelitian diperoleh bahwa rata-rata tingkat pengetahuan sebelum intervensi 252 (78.0 \%) memiliki pengetahuan yang baik dan meningkat menjadi 307 (95.0\%) memiliki pengetahuan yang baik tentang sarapan sehat setelah intervensi. Pada variabel sikap diperoleh hasil bahw perbedaan rata-rata sikap sebelum intervensi 256 (79.3\%) memiliki sikap mendukung dan meningkat menjadi $316(97.8 \%)$ sikap mendukung.Terdapat pengaruh intervensi terhadap pengetahuan dan sikap siswa $(\mathrm{p}=0,000)$.

Kesimpulan: Edukasi kesehatan mempengaruhi sikap dan pengetahuan siswa tentang sarapan. Saran: Disarankan bagi sekolah untuk menggunakan metode belajar menggunakan video dan poster dalam meningkatkan tingkat pengetahuan dan sikap siswa.
\end{abstract}

Kata kunci: Pendidikan Kesehatan, Pengetahuan, Sarapan, Sikap, Siswa. 


\section{The Influence of "Healthy Breakfast" Health Education with Video Media on Students' Knowledge and Attitudes}

\section{Abstract}

Background: Breakfast is important for the growth and development of children, but is often neglected, this can pose a risk to children's health and children's learning achievement.

Objective: To determine the effect of "Breakfast" health education on the knowledge and attitudes of elementary school students.

Methods: The study was conducted in the District of Bojong Asih, Leuwi Bandung, Cangkuang, and Pasawahan Elementary School. Quasi-experimental research was used with pre-test and post-test designs. The population was all 4-3 grade students totaling 323 students. The sample used was total sampling. Interventions were given in the form of health education using videos about healthy breakfast. All students were given quisioners before the intervention to measure their level of knowledge and attitude.

Results: The results showed that the average level of knowledge before intervention 252 (78.0\%) had good knowledge and increased to 307 (95.0\%) had good knowledge about healthy breakfast after intervention. On the attitude variable, the difference in attitudes before intervention $256(79.3 \%)$ had a supportive attitude and increased to 316 (97.8\%) attitudes of support. There was an effect of intervention on students' knowledge and attitudes $(p=0,000)$.

Conclusion: Health education affects students' attitudes and knowledge about breakfast.

Suggestion: It is recommended for schools to use learning methods to use videos and posters in increasing the level of knowledge and attitudes of students.

Keywords: Attitude, Breakfast, Health educaton, Knowledge, Student.

\section{PENDAHULUAN}

Sarapan pagi merupakan bagian dari

perilaku untuk mewujudkan gizi seimbang yang penting bagi hidup sehat, aktif dan cerdas bagi anak (Meriska, Pramudho \& Murwanto, 2014). Sarapan merupakan suatu hal yang penting bagi pertumbuhan dan perkembangan anak, tetapi sering diabaikan akibat dari adanya pengetahuan yang tidak memadai dan sikap yang tidak baik tentang pentingnya sarapan, yang akhirnya dapat beresiko pada kesehatan anak dimasa yang akan datang.
Sarapan juga dapat mengganggu pada konsentrasi belajar anak yang berdampak pada prestasi belajar anak akibat menurunkan semangat belajar. Hasil penelitian Verdiana dan Muniroh (2017) pada 43 siswa kelas V di SDN Sukoharjo I Kota Malang menunjukan bahwa kebiasaan sarapan pada anak memiliki hubungan yang bermakna dengan tingkat konsentrasi belajarnya.

Pengetahuan dan sikap anak yang baik tentang sarapan sangatlah penting, mengingat anak pada usia sekolah adalah merupakan 
generasi penerus bangsa, mereka sangat peka

untuk menanamkan pengertian dan kebiasaan

hidup sehat, serta merupakan usia dalam masa

tumbuh dan berkembang (Kosasih, Solehati,

Lukman, 2018). Dengan memiliki

pengetahuan yang memadai dan sikap yang

mendukung maka akan terbentuk pola perilaku

yang baik dalam melakukan sarapan sehat setiap pagi.

Pengetahuan merupakan hasil tahu seseorang terhadap objek melalui indra yang dimilikinya, sebagian besar diperoleh melalui indra pendengaran serta penglihatan. Pengetahuan memiliki peranan penting di dalan kehidupan seseorang, terutama dalam prilaku kehidupan sehari-harinya (Notoatmodjo, 2012).. Dengan pengetahuan memadai akan mendorong seseorang untuk memiliki sikap yang baik. Menurut Saifuddin (2013), sikap merupakan respons yang masih tertutup dari seseorang terhadap stimulus atau objek yang diterima. Pengetahuan akan mempengaruhi pada sikap seseorang. Hasil penelitian Palimbo, Firdaus \& Rafiah (2014) membuktikan bahwa hubungan antara pengetahuan dengan sikap.

Pengetahuan dan sikap yang kurang baik menyebabkan kurang sadarnya orang tua dan anak akan pentingnya sarapan sering menimbulkan masalah kesehatan pada anak dan masalah konsentrasi pada belajar. Ada beberapa faktor penyebab anak tidak melakukan sarapan pagi, seperti pengetahuan gizi anak, etersediaan makanan untuk sarapan pagi, dukungan keluarga, dan peran guru. Hasil penelitian Meriska, Pramudho \& Murwanto (2014) pada siswa SD di Kelurahan Kemiling Pemai menunjukkan bahwa ada hubungan antara pengetahuan gizi anak, ketersediaan makanan untuk sarapan pagi, dukungan keluarga, dan peran guru dengan perilaku sarapan pagi, dimana ketersediaan makanan untuk sarapan pagi merupakan variabel yang paling dominan berhubungan dengan perilaku sarapan pagi pada anak.

Untuk mengatasi masalah tersebut di atas adalah dengan memberikan pendidikan kesehatan kepada siswa. Menurut Salaudeen (2011), pendidikan kesehatan secara statistik 
berpengaruh pada peningkatan pengetahuan.

Dengan pendidikan kesehatan diharapkan siswa akan memiliki pengetahuan yang memadai tentang sarapan sehat sehingga terbentuk sikap yang mendukung, sehingga terbentuk perilaku yang mendukung pada pola sarapan sehat dalam kehidupan sehari-harinya. Penelitian Curtis, et all (2001) di Burkina Faso membuktikan bahwa pendidikan kesehatan dapat merubah perilaku menjadi sehat.

Pendidikan kesehatan yang diberikan melalui anak-anak sekolah efektif dalam merubah perilaku dan kebiasaan hidup sehat umumnya (Solehati, T., Susilawati,S., Lukman,M. \& Kosasih, C.E., 2015). Institusi pendidikan dipandang sebagai sebuah tempat strategis untuk mempromosikan kesehatan sekolah, juga tempat yang efektif mewujudkan pendidikan kesehatan. Dalam menyampaikan pendidikan kesehatan kepada anak diperlukan metode edukasi yang menarik perhatian anak dan tidak membosankan. Video adalah salah satu metode edukasi yang menarik bagi anak. Hal ini karena penggunaan media video didalam kegiatan pembelajaran tidak hanya sebagai alat bantu saja dalam menyampaikan informasi, tetapi juga sebagai membawa informasi atau pesan yang ingin disampaikan, serta dalam proses pemberianya responden tidak hanya mendengar materi yang sedang disampaikan, tetapi juga melihat secara langsung dan jelas tentang apa yang disampaikan oleh pemberi materi

\section{Bahan dan Metode}

Penelitian dilakukan di SDN Bojong Asih, SDN Pasawahan, SDN Cangkuang, SDN Leuwi Bandung Kecamatan Dayehkolot Kabupaten Bandung tahun 2017. Desain pada penelitian ini adalah quasi eksperimen dengan rancangan pre test dan post test. Populasi pada penelitian ini adalah seluruh siswa siswa kelas 4-6 tersebut berjumlah 323orang di keempat SDN tersebut. Sample yang digunakan adalah total sampling. Intervensi diberikan dengan menggunakan metode CTJ interaktif menggunaan video tentang sarapan sehat.

Semua siswa diberikan quisioner sebelum intervensi dilakukan kemudian diberikan edukasi kesehatan tentang sarapan 
sehat yang meliputi pengertian sarapan sehat

dan bergizi, jenis-jenis sarapan sehat dan

bergizi, kegunaan sarapan, dampak tidak

sarapan. Setelah intervensi diberikan maka

siswa diberikan quisioner kembali untuk mengukur tingkat pengetahuan dan sikap

mereka.

Analisa yang digunakan dalam penelitian ini adalah analisis data univariat (persentase) untuk mengetahui distribusi pengetahuan dan sikap serta bivariat ( $\mathrm{t}$ test) mengetahui pengaruh edukasi kesehatan terhadp pengetahuan dan sikap.

\section{Hasil Penelitian}

Langkah kegiatan yang telah dilakukan berupa pretest pada siswa kemudian pemberian edukasi kesehatan terkait dengan sarapan sehat dan bergizi. Kemudian diakhiri dengan post test. Hasil yang didapatkan dapat dilihat pada tabe -tabel di bawah ini:

a. Tingkat pengetahuan pada siswa Tabel 1. Distribusi frekuensi tingkat pengetahuan siswa tentang sarapan sehat sebelum dan setelah intervensi tahun 2017 $(n=323)$.

\begin{tabular}{crrrrr}
\hline $\begin{array}{c}\text { Tingkat } \\
\text { Pengetahuan }\end{array}$ & \multicolumn{2}{c}{$\begin{array}{c}\text { Sebelum } \\
\text { Intervensi }\end{array}$} & \multicolumn{2}{c}{$\begin{array}{c}\text { Setelah } \\
\text { Intervensi }\end{array}$} \\
\hline & $f$ & $\%$ & \multicolumn{2}{c}{$f$} & $\%$ \\
\hline $\begin{array}{c}\text { Sarapan Sehat } \\
\text { dan Bergizi }\end{array}$ & Baik & 252 & 78.0 & 307 & 95.0 \\
\hline & Buruk & 71 & 22.0 & 16 & 5.0 \\
\hline Total & & 323 & 100. & 323 & 100 \\
\hline
\end{tabular}

Dari tabel 1. dapat diketahui bahwa rata-rata tingkat pengetahuan tentang sarapan sehat dan bergizi, sebelum intervensi sebagian besar responden $252(78.0 \%)$ memiliki pengetahuan yang baik. Setelah intervensi mengalami perubahan tingkat pengetahuan menjadi sebagian besar responden $307 \quad(95.0 \%)$ memiliki pengetahuan yang baik.

Tabel 2. Perbedaan rata-rata tingkat pengetahuan siswa sebelum dan setelah intervensi tahun 2017 $(n=323)$

\begin{tabular}{ccccccc}
\hline & \multicolumn{2}{c}{$\begin{array}{c}\text { Sebelum } \\
\text { intervensi }\end{array}$} & \multicolumn{2}{c}{$\begin{array}{c}\text { Setelah } \\
\text { intervensi }\end{array}$} & $\boldsymbol{z}$ & $\boldsymbol{p}$ \\
\cline { 1 - 5 } $\begin{array}{c}\text { Tingkat } \\
\text { pengetahuan }\end{array}$ & Mean & SD & Mean & SD & & \\
\cline { 1 - 5 } $\begin{array}{c}\text { Sarapan Sehat } \\
\text { dan Bergizi }\end{array}$ & 3.21 & 1.101 & 3.65 & $\begin{array}{c}.62 \\
0\end{array}$ & -8.622 & 0.000 \\
\hline
\end{tabular}

Tabel 2. Menunjukan bahwa terdapat perbedaan rata rata tingkat pengetahuan sebelum dan setelah intervensi pada siswa $(\mathrm{pv}=0,00)$

b. Sikap siswa

Tabel 3. Distribusi frekuensi sikap siswa sebelum dan setelah intervensi tahun 2017 $(n=323)$.

\begin{tabular}{|c|c|c|c|c|c|}
\hline \multirow[t]{2}{*}{ Komponen } & \multirow[t]{2}{*}{ Sikap } & \multicolumn{2}{|c|}{$\begin{array}{l}\text { Sebelum } \\
\text { Intervensi }\end{array}$} & \multicolumn{2}{|c|}{$\begin{array}{c}\text { Setelah } \\
\text { Intervensi }\end{array}$} \\
\hline & & $f$ & $\%$ & $f$ & $\%$ \\
\hline $\begin{array}{l}\text { Sarapan } \\
\text { Sehat dan } \\
\text { Bergizi }\end{array}$ & Mendukung & 256 & 79.3 & 316 & 97.8 \\
\hline & $\begin{array}{l}\text { Tidak } \\
\text { mendukung }\end{array}$ & 67 & 20.7 & 7 & 2,2 \\
\hline Total & & 323 & 100 & 323 & 100 \\
\hline
\end{tabular}

Dari tabel 3. dapat diketahui bahwa rata-rata sikap sebelum intervensi $256 \quad(79.3 \%)$ memiliki sikap mendukung. Setelah intervensi mengalami perubahan sikap menjadi 316 (97.8\%) sikap mendukung. 
Untuk mengetahui pengaruh edukasi kesehatan terhadap sikap siswa, maka perlu diketahui perbedaan rata-rata sikap sebelum dan setelah periode intervensi. Berikut ini akan dijelaskan mengenai perbedaan tersebut, yaitu:

Tabel 4. Perbedaan rata-rata sikap siswa sebelum dan setelah intervensi tahun $2017(\mathrm{n}=323)$

\begin{tabular}{|c|c|c|c|c|c|c|}
\hline \multirow[t]{2}{*}{ Sikap } & \multicolumn{2}{|c|}{$\begin{array}{c}\text { Sebelum } \\
\text { intervensi }\end{array}$} & \multicolumn{2}{|c|}{ Setelah intervensi } & \multirow[t]{2}{*}{$z$} & \multirow[t]{2}{*}{$p$} \\
\hline & Mean & $S D$ & Mean & $S D$ & & \\
\hline $\begin{array}{l}\text { Sarapan } \\
\text { Sehat } \\
\text { dan } \\
\text { Bergizi }\end{array}$ & 3.21 & 1.101 & 3.65 & 0.620 & -8.622 & 0.000 \\
\hline
\end{tabular}

Tabel 4. Menunjukan bahwa terdapat perbedaan rata rata sikap pada sarapan sehat sebelum dan setelah intervensi pada siswa $(\mathrm{p}=0,000)$

\section{Pembahasan}

Berdasarkan hasil penelitian pada siswa di SDN Bojong Asih, SDN Pasawahan, SDN Leuwi Bandung, dan SDN Cangkuang Wetan Dayeuhkolot diperoleh hasil bahwa tingkat pengetahuan dan sikap siswa mengalami peningkatan setelah dilakukan edukasi kesehatan dengan menggunakan media video. Hasil pelatihan yang dilakukan secara signifikan berbeda antara pretest dan post test tentang sarapan sehat $(\mathrm{p}<0.05)$.

Pemberian edukasi melalui video membuat siswa tertarik untuk memperhatikan informasi yang diberikan kepada mereka sehingga pengetahuan mengalami peningkatan. Video merupakan media edukasi yang menarik dan tidak membosankan bagi anak. Penelitian Hamida (2012), menemukan bahwa media yang digunakan dalam proses pembelajaran menyebabkan proses pembelajaran menjadi lebih menarik perhatian sehingga lebih mudah dipahami serta sasaran tidak menjadi cepat bosan. Hal ini didukung dengan hasil penelitian Rufiati (2011), dan Zulaekah (2012) yang menemukan bahwa penggunaan media dalam pemberian edukasi dapat mempengaruhi peningkatan pengetahuan.

Selain dapat meningkatkan tingkat pengetahuan, edukasi dengan menggunakan media video juga dapat meningkatkan sikap seseorang. Pada penelitian ini ditemukan bahwa sikap mengalami peningkatan kearah mendukung sarapan setelah dilakukan intervensi edukasi kesehatan. Hasil penelitian Siwi, Yunitasari \& Krisnana, (2014) pada siswa SDN Seduri dan siswa SDN Singkalan membuktikan bahwa media audio visual 
mempunyai pengaruh yang signifikan terhadap sikap anak.

Edukasi dengan menggunakan video ini tentunya tidak hanya terbatas pada materi tentang sarapan sehat saja, akan tetapi untuk hal-hal lain dimana kebutuhan peningkatan pengetahuan dan sikap diperlukan pada berbagai aspek karena selama ini pun mereka dihadapkan pada permasalahan-permasalahan yang mereka sendiri perlu mendapatkan bantuan. Dengan pengetahuan yang memadai serta sikap yang mendukung kesehatan diharapkan mereka dapat mengaplikasikan kedalam perilaku melakukan sarapan sehat dan bergizi dalam kehidupan sehari-hari, serta dapat mempengaruhi orang lain untuk berperilaku sehat tersebut.

\section{Kesimpulan Dan Saran}

\section{Kesimpulan}

Edukasi kesehatan mempengaruhi sikap dan pengetahuan siswa tentang sarapan.

\section{Saran}

Disarankan bagi sekolah untuk menggunakan metode belajar menggunakan video dan poster dalam meningkatkan tingkat pengetahuan dan sikap siswa.

\section{Daftar Pustaka}

Aeni, N. \& Yuhandini, D.S. (2018). Pengaruh Pendidikan Kesehatan Dengan Media Video Dan Metode Demonstrasi Terhadap Pengetahuan SADARI. Jurnal Care. 2, 6 (2): 162-174

Curtis, Kanki,B., Cousens,S., Diallo,I., Kpozehouen,A., Sangare,M.'\& Nikiema,M. 2001. Evidence of behaviour change following a hygiene promotion programme in Burkina Faso Valerie. Bulletin of the World Health Organization. 79 (6):518-527

Hamida, K., Zulaekah,S.,\& Mutalazimah. 2012. Penyuluhan Gizi Dengan Media Komik Untuk Meningkatkan Pengetahuan Tentang Keamanan Makanan Jajanan. Jurnal Kemas.8 (1) $67-73$

Kosasih, C.E., Solehati, T. \& Lukma, M. (2018). Pengaruh Edukasi Kesehatan Bahaya Rokok Terhadap Pengetahuan dan Sikap Siswa Sekolah Dasar. Jurnal Kesehatan Poltekkes Ternate.11 (1): 18

Meriska, I., Pramudho, K. \& Murwanto, B. (2014). Perilaku Sarapan Pagi Anak Sekolah Dasar. Jurnal Kesehatan. 5 (1); 90-97

Muniroh, L. \& Verdiana, L. (2017). Kebiasaan Sarapan Berhubungan dengan Konsentrasi Belajar Pada Siswa SDN Sukoharjo I Malang. Media Gizi Indonesia. 12 (1): 14-20 
Notoatmodjo, S. (2012). Metodologi Penelitian Kesehatan. Rineka Cipta, Jakarta.

Palimbo, A., Firdaus, F. \& Rafiah .(2014). Pengetahuan dan Sikap Ibu Hamil Terhadap Kejadian Kekurangan Energi Kronis (KEK). Dinamika Kesehatan. 5 (2); 1-10

Rufati, A.M., Raharjo, B.B., \& Indrawati., F. 2011. Pengaruh Metode Permainan Find Your Mate Terhadap Peningkatan Pengetahuan Kader Posyandu. Jurnal Kemas. 6(2): 113-119.

Saifuddin, A. (2013). Sikap Manusia Teori dan pengukurannya. Jogyakarta: Pustaka Pelajar

Salaudeen, A., Musa, O., Akande, T., Bolarinwa, O. 2011. Effects of Health Education on Cigarette Smoking Habits of Young Adults in Tertiary Institutions in a Northern Nigerian State. Health Science Journal, 5, Issue 3.

Siwi, L.R., Yunitasari,E. \& Krisnana, I. (2014).Meningkatkan Perilaku Konsumsi Jajanan Sehat Pada Anak Sekolah Melalui Media Audio Visual. Jurnal Pediomaternal. 3 (1) : 1-8

Solehati, T., Susilawati, S., Lukman, M. \& Kosasih C.E.. (2015). Pengaruh edukasi terhadap pengetahuan dan skill guru serta personal hygiene siswa SD Jurnal Kesehatan Masyarakat 11 (1), 135-143

Zulaekah, S. 2012. Efektivitas Pendidikan Gizi Dengan Media Booklet Terhadap Pengetahuan Gizi Anak SD. Jurnal Kemas.7(2): 121-128 